DOI: https://doi.org/10.32839/2304-5809/2019-3-67-74

UDC 811.111.81’37

Tahiltseva Yanina, Tiurina Karyna, Sakharova Liudmyla

Poltava State Agrarian Academy

\title{
USE OF ANTONYMS IN ENGLISH PROVERBS AND SAYINGS
}

Summary. The article deals with the study of antonyms used in English proverbs and sayings. A comprehensive analysis of antonymic relations, proposed in our work, is carried out at lexical, morphological, syntactical and cultural level. Antonyms are classified according to the semantic criterion (gradual, complementary, converse and vector ones). Depending on a part of speech it has been found out that antonyms within English paroemiae are expressed by adjectives, nouns, verbs, adverbs, pronouns. Besides, antonymic relations are considered within certain topical sets of proverbs and sayings. The lexical categories of antonyms used in paroemiae have been identified (a value of quality, opposite coordinates, time, quantity). Stable syntactic models of the folk statements under consideration are studied. Their functions are highlighted. The role of antonyms in proverbs and sayings is emphasized.

Keywords: linguistics, antonyms, proverbs and sayings, paroemia, lexicology, morphology, syntax.

Тагільцева Я.М., Тюріна К.О., Сахарова Л.М. Полтавська державна аграрна академія

\section{ВИКОРИСТАННЯ АНТОНІМІВ У АНГЛІЙСЬКИХ ПРИСЛІВ'ЯХ ТА ПРИКАЗКАХ}

Анотація. У статті досліджуються особливості використання антонімів у англійських прислів’ях та приказках. Подається визначення антонімії як парадигматичного явища, що спостерігається у різножанрових текстах. Цілісний аналіз антонімічних відношень здійснюеться на лексичному, морфологічному, синтаксичному і культурологічному рівнях. Запропоновано класифікацію антонімів, що вживаються в англійських пареміях, за семантичним критерієм, згідно з яким їх поділено на градуальні, комплементарні, векторні та конверсиви. У межах градуальних виявлено використання якісних прикметників та прислівників. Комплементарні антоніми представлені прикметниками, що виражають абсолютну якість та іменниками з абстрактним і конкретним значенням. Серед конверсивів переважають іменники на позначення взаємозалежності, суміжності, зворотних зв'язків тощо. Векторні антоніми презентують фразові дієслова, що виражають протилежні дії, явища, характеристики і т. ін. З'ясовано, що залежно від частиномовної приналежності антонімами в англійських пареміях виступають прикметники, іменники, дієслова, прислівники, займенники. Також антонімічні відношення розглядаються в межах певних тематичних груп прислів їв та приказок (видимість, сутність; вік; сподівання; ризик; родинні стосунки; упертість; байдужість, безвідповідальність; сила, слабкість). Визначено лексичні категорії антонімів, що вживаються в англійських пареміях (міра якості, протилежні позиції, час, кількість). Крім того увага авторів фокусуеться на типових синтаксичних моделях народних висловлювань з антонімічними зв'язками, серед яких виділяються прості речення, складні структури із з'єднувальними словами і без, умовні і наказові речення. Висвітлюються фрункції синтаксичних конструкцій, у межах яких функціонують антоніми. Наголошуеться на тому, що використання протилежних за значенням слів надають висловлюванню стислості, природності, допомагають виразити ідею чітко і лаконічно. Встановлюеться роль антонімів у англійських прислів'ях та приказках як експресивної, перцептивної, культурологічної рефрлексії.

Ключові слова: лінгвістика, антонім, прислів’я, приказка, паремія, лексикологія, морфологія, синтаксис.

The statement of the problem. It is well

1 known that national mentality is manifested in people's everyday life, customs, history and culture, which are the basis of folk art. In our opinion, folklore is that kind of material that helps researchers not only to investigate some moral and ethical values of people, their life experience, world perception, but it is a huge platform for comprehensive study of the language.

The problem of antonymic relations in English proverbs and sayings, chosen for the consideration in our scientific paper, has not been raised yet at the scientific level. Investigation of antonyms is of great importance for linguistic science, as they are a significant part of language vocabulary, make it more expressive and multivarious, as well as influence communicational culture and speech pattern. We think that the system analysis of antonyms used in English proverbs and sayings will contribute to further research not only in the field of linguistics and literature, but psycho-, ethno-linguistics and even some pedagogical issues.
The analysis of the latest research and publications. It should be mentioned that the problems of antonymy are not new in linguistics at present time. Some Ukrainian scientists are interested in them. Starovoitova O.V. [6] has been considered the peculiarities of interaction between synonyms and antonyms in the English language. Antonymic relations were the object of the research by Biian N.R. [1] where the scholar investigated the English terms of tourism. Foreign researchers paid their attention to the problem of phraseological antonymy (Varfolomeeva N.S. [3]), the origin of this phenomenon and its specific features (Fernald J.Ch. [11]), grammar antonymy in modern English (Boeva N.B. [2]), a linguistic study of the given type of semantic relations in English texts (Chunming Gao and Qianzhen Zheng [10]), etc.

The problem of proverbs and sayings was a focus of Ukrainian linguists. Orlovska O.V. [5] compared English and Ukrainian paroemiae. The structure of English proverbs was studied by 
Ovsianko O. [4]. Taranenko L. [7] analyzed the text of English proverbs in terms of their genre characteristics and functional features. The Belorussian scientist A. Prokopchik [12] investigated English proverbs and peculiarities of their translation into Russian.

Unsolved problems under consideration. Hence, paroemiae and antonyms are the object of study in a diverse linguistic context. Inspite of such a range of research the question concerning the peculiarities of antonyms in paroemiae has not been investigated yet, which determines the urgency of our research.

The object of our work is such paroemia units as proverbs and sayings in the English language. The subject is antonyms used in English paroemiae. The goal of the article is to study the specific features of antonyms in the given kind of folk statements.

The main part. It should be mentioned that some English proverbs and sayings consist of two symmetrical parts, in which certain phenomena are compared or contrasted:

Better glorious death than a shameful life.

Better wear out than rust out.

The bird is created for flight and the man is for work.

A separate group of English paroemiae is presented by those that include antonyms expressing the opposite orientation of actions, properties, qualities, names, etc:

The full ear rotates to the ground, and the empty hinges up.

More haste, less speed.

Success has many fathers, while failure is an orphan.

This group is a focus of our consideration.

A comprehensive analysis of antonyms in English proverbs and sayings, proposed in our work, is carried out in the following directions: lexical, morphological, syntactical and cultural, which will help to identify the peculiarities of paroemiae at the linguistic and mental levels. As Vorkachev said, "Language, culture and ethnos are inextricably connected and form the essence of the personality - the place of physical, spiritual and social conjunction" [4, p. 71].

Antonyms have been the subject of a thorough linguistic analysis for a long time. At the present stage, antonymy research is characterized by the fact that it is considered as a paradigmatic phenomenon, and the connection of antonymy with synonymy and polysemy is studied in detail. In addition, there is a tendency to study antonymic relations in specific speech usage in texts of different genres.

We consider antonyms as words with opposite lexical meanings, which are combined with a certain common factor: high - low (height), thick thin (state), cheerful - sad (mood).

According to the semantic criterion we have distinguished the following groups of antonyms: gradual, contractual, complementary, converse and vector.

Gradual antonyms comprise sets of lexical items within which intermediate opposition can be observed (hot - warm - cool - cold). They express a qualitative opposite, and therefore, this group is often presented by antonyms expressed by qualitative adjectives, as well as adverbs derived from qualitative adjectives (with qualitative or temporal meanings):

Better late than never.

Cold hands, warm heart.

Promise little, but do much.

Complementary antonyms do not involve intermediate elements. They express the opposition of two aspects belonging to one gender (life death, mother - father, etc.). This group mainly includes:

a) adjectives expressing absolute quality, or adjectives contrasted with the pronoun:

A full belly does not understand an empty one.

The full ear rotates to the ground, and the empty hinges up.

b) nouns with abstract and specific meanings:

Happiness runs, and misfortune lies.

Success has many fathers, while failure is an orphan.

Converse antonymy is also observed in English paroemiae. This type of semantic relations is characterized by interdependence, adjacency, casual links between the elements, their reversal relationships.

Ask a silly question and you'll get a silly answer.

Best defense is offence.

The exception which proves the rule.

Vector antonyms determine two opposite actions, phenomena, characteristics, directions, etc. They are presented in English proverbs and sayings as well and are mostly expressed by literal phrasal verbs: fleas.

If you lie down with dogs, you will get up with

What goes up must come down.

Depending on a part of speech we have distinguished the following groups of antonyms in the structure of proverbs and sayings:

1. Antonyms expressed by adjectives (in positive and superlative degree):

Hope for the best, but prepare for the worst.

A civil denial is better than a rude grant.

A clean fast is better than a dirty breakfast.

This is the largest group, which can be explained by the fact that in proverbs and sayings certain statements are often based on the opposition of certain characteristics.

2. Antonyms presented by nouns. It should be mentioned that abstract names are normally used within this group:

Keep your friends close and your enemies closer.

A bad compromise is better than a good lawsuit.

A friend's frown is better than a foe's smile.

3. Antonyms expressed by verbs:

It's better to give than to receive.

Easy come easy go.

Never put off until tomorrow what you can do today.

If it ain't broke, don't fix it.

You win some, you lose some.

4. Antonyms - adverbs. Adverbs of adjective origin are often present in this group: 
Better late than never.

More haste, less speed.

5. Antonyms - pronouns. The opposition 'defining pronoun and negative one' is dominant in this category:

Jack of all trades and master of none.

Everybody's business is nobody's business.

Besides, we have found antonymic relations within certain topical sets of English proverbs and sayings, that is:

a) visibility and essence: A black hen lays a white egg. The smallest axe may fell the hugest oak.

b) age: An old dog will learn no new tricks.

c) hope, expectation: An hour in the morning is worth two in the evening.

d) risk: Either to win the horse or lose the saddle.

e) family relationships: The black crow thinks her own birds white.

f) stubbornness: A wise man changes his mind, a fool never will.

g) indifference, irresponsibility: Everybody's business is nobody's business.

h) strength-weakness: Little strokes fell great oaks.

In our opinion, antonyms in any given topical set of paroemiae make such a contrast that helps to emphasize people's evaluation of objective phenomenon of reality, national mentality, spirit and character, customs and morals, beliefs and superstitions, etc.

Linguist Shmelev D.M. says: "The most complete opposition of words is regarded as antonymy. Antonymic words can be recognized, which are contrasted with the most general and meaningful semantic sign, and are at the extreme points of the corresponding lexical-semantic paradigm" [8, p. 335].

Consequently, the antonymic pairs combine words that necessarily have three characteristics: 1) incompatible signs, 2) homogeneous signs, 3) dichotomy (the ability to divide into two parts) of a common genetic sign.

Taking into account these features, antonyms include words with various semantic meanings. We have identified the following lexical categories of antonyms in the structure of English proverbs and sayings:

1) a value of quality: Big fish eat little fish. Don't get mad, get even.

2) opposite coordinates: A good beginning makes a good ending. If you lie down with dogs, you will get up with fleas. What goes up must come down.

3) time: Better late than never. An hour in the morning is worth two in the evening. An old dog will learn no new tricks.

4) quantity: Everybody's business is nobody's business. Jack of all trades, master of none.

Paroemiae with opposites secure stable syntactic models. Also, in English such paroemiae are productively presented by:

- simple sentences: Little strokes fell great oaks. A civil denial is better than a rude grant.

- impersonal: Better late than never. It's better to give than to receive.

- complex sentences with linking words and without them: Hope for the best, but prepare for the worst. Happiness runs, and misfortune lies. Success has many fathers, while failure is an orphan. You win some, you lose some.

- conditionals: If you lie down with dogs, you will get up with fleas.

- imperatives: Easy come easy go.

It is necessary to say that these models perform certain functions. Simple sentences, impersonal and imperatives make the statement condensed and natural, complex and conditional structures emphasize the contrast and help to express the idea clearer.

Some scientists indicate that antonymy has "supernatural" quality: "Opposite in meaning words possess a unique property. For example, simultaneous proximity and remoteness of antonyms from each other. Meaning of antonymic pairs intuitively seems as much detached as possible. And there is some kind of supernatural power, which unites two words with opposite meaning. Philosophers and scientists indicate on ability of things to manifest opposite abilities; and many people noted that there was a fine line between love and hate, genius and craziness" [10, p. 197]. That is, every antonymic pair, describing one essence, demonstrate its ambivalent character, which permeated objective reality. We can say that opposite as notion is one of characteristic manifestation of nature addiction human mind and underlie various phenomena in everyday life, scientific knowledge, philosophical construction, ethics, aesthetics, religion, etc.

Conclusions. The analysis of English paroemiae reveals the structural, grammatical and semantic features of the antonymic paradigm of the folk text. In addition, the analysis of paroemiae of the English language makes it possible to reveal the specifics of the national character, especially the value perception of reality, as the best way to give an exhaustive description of the phenomena of reality is to compare. Having analyzed English proverbs and sayings, in particular the antonymic relations in them, we can highlight several features of the English: they are rational, hardworking, freedom-loving, independent, discreet, careful and prudent people. The brightest contrast values are expressed by lexical antonyms.

Thus, antonyms in English paroemiae help to describe contrasts, which make up people's life, national customs, traditions, history, culture, in the most expressive and clearest way. Antonyms in English proverbs and sayings serve to confirm the purpose of the paroemiae to transfer the experience of the people accumulated over the centuries, their spiritual values, and world perception.

Consequently, the use of antonyms and paroemiae in the language makes it more expressive, richer, more contrasting, enables to focus on certain phenomena and distinguish them.

The analysis of English paroemiae shows how diverse can be the structure of the antonymic paradigm, which goes beyond the ordinary, common language applications for the realization of didactic goals (as learning the vocabulary by remembering antonymic pairs facilitate learning of the language) and the study of national culture. 


\section{References:}

1. Biian N.R. (2013). Antonimichni terminy haluzi turyzmu [Antonymic terms in the field of tourism]. Naukovi zapysky. Seriia "Filolohichna" [Scientific proceedings. Issue "Philology"], vol. 36, pp. 6-10.

2. Boeva N.B. (2001). Grammaticheskaya antonimiya v sovremennom angliyskom yazyke [Grammar antonymy in modern English] (PhD Thesis). Moscow : Moscow State Pedagogical University.

3. Varfolomeeva N.S. (2001). Sravnitelno-sopostavitelnyy analiz frazeologicheskoy antonimii [Comparative analysis of phraseological antonymy] (PhD Thesis). Moscow : Moscow Pedagogical University.

4. Vorkachev S.G. (2001). Lingvokulturologiya, yazykovaya lichnost, kontsept: stanovleniye antropotsentricheskoy paradigm v yazykoznanii [Cultural linguistics, linguistic persona, concept: establishment of anthropocentric paradigm in linguistics]. Filologicheskie nauki [Philological sciences], № 1, pp. 64-72.

5. Ovsianko O. (2015). Hlobalna struktura anhliiskykh prysliviv: typolohichni aspekty [Global structure of English proverbs: typological aspects]. Available at: https://essuir.sumdu.edu.ua (accessed 23 February 2019).

6. Orlovska O.V. (2016). Anhliiski ta ukrainski paremii [English and Ukrainian paremias]. Aktualni problemy filolohii ta perekladoznavstva [Urgent problems of philology, translation and interpretation studies], vol. 10, pp. 247-250.

7. Starovoitova O.V. Koreliatsiia synonimiv ta antonimiv u systemi anhliiskoi movy [Correlation of synonyms and antonyms in the system of the English language]. Available at: https://dspace.udpu.edu.ua (accessed 23 February 2019).

8. Taranenko L. (2015). Zhanrovi osoblyvosti ta funktsionalne pryznachennia tekstu anhliiskoho pryslivia [Genre peculiarities and functional use of the English proverb text]. Naukovi zapysky. Seriia "Filolohichna" [Scientific proceedings. Issue "Philology"], vol. 53, pp. 244-247.

9. Shmelev D.N. (1977). Sovremennyy russkiy yazyk. Leksika : uchebnoe posobie [Modern Russian. Lexicology: manual]. Moscow : Prosveshchenie. (in Russian)

10. Cruse D.A. (1986). Lexical Semantics. Cambridge : Cambridge University Press.

11. Chunming Gao and Qianzhen Zheng (2014). A linguistic study of antonymy in English texts. Journal of Language Teaching and Research. Vol. 5. № 1, pp. 234-238. Available at: http://www.academypublication.com/ (accessed 10 February 2019).

12. Fernald J.Ch. (2009). English synonyms and antonyms. Osnova.

13. Prokopchik A. (2017). English proverbs and peculiarities of their translation into Russian. Available at: http://rep.barsu.by/ (accessed 20 February 2019). 